\title{
Madrasas and Social Mobility in the Religious Economy: The Case of Nadwat al-'Ulama in Lucknow
}

Christopher B. Taylor

\section{OpenEdition}

\section{Journals}

Electronic version

URL: http://journals.openedition.org/samaj/3932

DOI: $10.4000 /$ samaj.3932

ISSN: 1960-6060

Publisher

Association pour la recherche sur l'Asie du Sud (ARAS)

\section{Electronic reference}

Christopher B. Taylor, « Madrasas and Social Mobility in the Religious Economy: The Case of Nadwat al-'Ulama in Lucknow », South Asia Multidisciplinary Academic Journal [Online], 11 | 2015, Online since 15 July 2015, connection on 30 April 2019. URL : http://journals.openedition.org/samaj/3932 ; DOI : 10.4000/samaj.3932

This text was automatically generated on 30 April 2019.

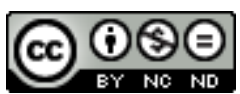

This work is licensed under a Creative Commons Attribution-NonCommercial-NoDerivatives 4.0 International License. 


\title{
Madrasas and Social Mobility in the Religious Economy: The Case of Nadwat al-'Ulama in Lucknow
}

\author{
Christopher B. Taylor
}

\section{AUTHOR'S NOTE}

This article is based on research conducted with the assistance of the National Science Foundation (Grant No. DGE-1247312). I would like to thank Sandria Freitag, Filippo Osella, Robert Hefner, Charles Lindholm, and four anonymous reviewers for their comments on prior versions of this work.

\section{Introduction}

1 The madrasa (Islamic seminary) of Dar al-'Ulūm Nadwat al-'Ulama was constructed in Lucknow in 1906 on the bank of the river Gomti in Lucknow. Nadwa (as the madrasa is locally known) overlooks a wide swath of the city-scape of old Lucknow (qadimi lacknau) across the river. 'New' Lucknow, such as the neighbourhoods of Gomti Nagar and Aliganj, have filled in behind Nadwa as urban development has ballooned to the north and easteffectively making Nadwa the geographical centre of this expanding provincial capital. For many ordinary north Indians, however, this madrasa and the 'traditional' Islamic identity it is perceived to represent seem increasingly out-of-place in the $21^{\text {st }}$ century.

Nadwa is one of the most famous among India's reformist madrasas, and purportedly the country's largest after recently surpassing Deoband in student numbers (Zaman 2002: 160). Its founders envisioned an institution that would bring traditional Islamic learning into the modern world. Their hope in this regard was twofold. First, Nadwa would 'synthesize the profitable past with the useful modern' (Moosa 2007) by training 
religious scholars ('ulama) in the Islamic sciences combined with modern topics, such as the English language, that would enable them to interact with the world as ambassadors. Second, they imagined that Nadwa would rid Indian Islam of sectarianism by incorporating 'ulama of all groups into its 'conclave' (nadwat). In the heady environment of 19th century revivalism that spawned numerous Islamic movements, Nadwa's founders sought to unite them (Sikand 2005: 79). However, Nadwa's leadership failed to achieve 'as much reform as intended,' and most observers view Nadwa today as nearly as indistinguishable from Deoband as a traditional madrasa (Zaman 2002: 72).

3 As the institution charged with preservation of Islamic tradition in India, madrasas play a key role in reproducing Muslims' religious distinctiveness. However, many forwardthinking Lucknowis view Nadwa as clinging to outdated values. Recent concerns over militancy among radical Muslim groups (while unfounded) only heightened suspicion of Nadwa and what it symbolizes, such as in the 1995 night-time raid on Nadwa by police hunting for suspected terrorism links (Sikand 2005: 288-89). The Sachar Committee report (2006: 17) found substantial evidence for 'a general acceptance of an urgent need for the modernization of madrasas' and numerous government schemes have been launched. ${ }^{1}$ India's news media perennially publish articles repeating characterizations of madrasas as 'medieval' or keeping the Muslim community in a 'backward' mind-set. ${ }^{2}$ This critique emerges also within Muslim communities (Alam 2011:1-3). Imtiaz Ahmad (2002: 2285-7) questioned if madrasas are 'effective as education' at all in contemporary India. 'Now, times are changing. People are saying, 'I have no use for the madrasa system,' ' a businessman from a prominent Muslim family told me in Lucknow, 'because [students] study there [in madrasas] for eight years and still get no 'service' [jobs].'

4 Yet despite widespread perception of their declining usefulness and refusal to modernize, madrasas across India are increasing in number, size, and budgets. Nadwa in Lucknow now educates nearly 4,000 students, in addition to its dozens of affiliated branches across India. Madrasas in India were estimated to number over 30,000 (Sikand 2005: 95; Metcalf 2007: L14134; Riaz 2008: 173) and more are being opened annually in rural areas around Lucknow (as I observed) and elsewhere in Uttar Pradesh (Jeffrey et al. 2004). Jeffrey et al. (2004: 36) attributed such continued growth to the increased demand among all Indians for formal education, to increased income among rural Muslims that correspondingly increases donations to madrasas, and of course to increasing population. In the north Indian region that includes Uttar Pradesh and Lucknow city, 7\% of all school-enrolled Muslim students in 2002 attended a madrasa as opposed to a private or government school (Sachar 2006: 76), and since a vast majority of madrasas are for boys, this proportion could be as high as $10-13 \%$ of Muslim boys attending madrasas full-time (on girls' madrasas and their rarity, see Winkelmann 2005). ${ }^{5}$ Thousands of Indian Muslims continue to select a full-time madrasa education over government schools.

5 The bulk of criticism has centred on madrasa education as not being useful in modern times. By and large there is truth to assessments of madrasa schooling that identifies low quality of instruction, lack of resources, and low educational outcomes (Metcalf 2007). Yet the continued enrolments and even expansion of madrasas in India present a puzzle: do students-and Muslims more generally-perceive any practical usefulness or economic utility in a madrasa education?

6 This article illustrates how Nadwa madrasa exists within a religious sphere that is a marketplace for jobs in scholarship and ritual leadership, one that is undergirded by an economy of national and international proportions fuelled by almsgiving. I explain how 
students perceive the madrasa as (among its other roles) providing opportunities for lower class Muslims, linking village youth who had few educational prospects to skills and jobs in Lucknow's urban economy and beyond-and to channels for fundraising from donors in Lucknow, Delhi, and Bombay as well as Saudi Arabia and the Emirates.

Much recent social science research has remained mired in policy-related questions of 'modernization' reforms of South Asian madrasas and whether these have succeeded or failed (e.g. Hartung 2006b; Sikand 2006; Bano 2014; Malik 2007; Jhingran 2010; Basit 2012) although a few notable studies are exceptions (Sikand 2005; Winkelmann 2005; Metcalf 2007; Alam 2011; Moosa 2015). The approach of this article is to take a different tack in the study of madrasas and to investigate how madrasas are already 'modern' and emplaced within contemporary Indian society and economy. Rather than 'modernization,' I follow scholarship that has emphasized the 'modernity of tradition' (Rudolph \& Rudolph 1967) as embodied in Indian madrasas (Metcalf 1982, 2007; Zaman 1999, 2002; Ingram 2014).

Yet Nadwa's relevance today is distinct from the role played by reformist madrasas of the $19^{\text {th }}$ century in certain ways. Historical characterizations portray reformist madrasas as having led the Indian Muslim community in a strategy of an 'inward turn' to address societal problems by way of individual moral reform in Lucknow and elsewhere (Metcalf 1982: 5; Robinson 2008). This article illustrates the contemporary perspectives of Nadwa students and 'ulama on how madrasa education today has integrated them into society at large and prepared them to participate in India's modern economy. As educated religious specialists, Nadwa students gain cultural capital and translatable skills that lead to perceived social mobility-a turn outward and upward rather than 'inward' that represents progress on intertwined indices of moral and material development conducive to spreading Islamic ethics to the modern world.

In the three sections of ethnographic and interview data that follow, I discuss how Nadwa provides free education to significant numbers of Muslim students, resulting in perceived employment opportunities, as well as in other forms of social mobility that are highly salient such as gains in social status and overcoming caste barriers. These data shed light on north India's growing religious occupational sector and the transferable job skills obtained through Islamic studies. While maintaining that madrasa education stands in need of improvement, even at elite madrasas like Nadwa, students voiced considerable approval for the utility and value of a Nadwa education as compared to other available options. Such student perspectives given in this article, as I discuss in the conclusions, provide an indispensable contribution amidst India's growing public debate over the value of madrasas in the contemporary, globalizing economy.

Table 1: Representativeness of Stratified Network Sample for Student Interviews

\begin{tabular}{|l|l|l|}
\hline Type of Student & Sample & Institution \\
\hline Scholarship recipients & $64 \%(16 / 25)$ & $60 \%$ \\
\hline Senior students & $36 \%(9 / 25)$ & $33 \%$ \\
\hline
\end{tabular}




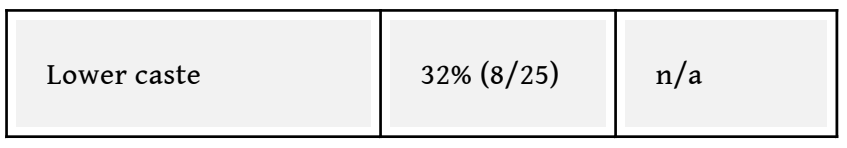

10 This article's data stem from 18 months of anthropological fieldwork in Lucknow during 2012-13 on public perceptions of the socioeconomic conditions of Muslims and attempts to address them. Data-gathering occurred most intensively during three months of study in Nadwa, which included participant observation in student residence areas during afternoons and evenings. I also administered a structured interview questionnaire, from which a portion of the interview quotes are drawn. The topical sections included: students' family backgrounds, prior education, motivations for enrolling in Nadwa, motivations for pursuing non-madrasa or university education (if any), and future career aspirations. I defined a sample of 25 student interviewees by using stratified, network sampling beginning with students randomly selected in two locations: the first-year hostel and the main mosque after prayers. These structured interviews-while not fully representative in the statistical sense-comprise a stratified quota sample that gives a proportional snapshot of the general student body of 3,000 students according to (a) socioeconomic status, i.e. scholarship-recipient versus fee-paying, (b) year, i.e. senior (last two years of the six-year 'alim degree) versus junior students, (c) caste, i.e. upper versus lower caste. ${ }^{6}$ The Nadwa administration generously granted me unique permission to administer the questionnaire but only for this sample size. Other quotations are drawn from unstructured interviewing and ethnographic observation, as noted.

\section{Free education in a time of state failure}

11 Madrasas are primarily viewed as preserves of Muslim tradition, but a secondary, often implicit theme that emerged during my research in Lucknow was their role in providing educational services to the poor. As one senior administrator at Nadwa told me,

If your research is on welfare, madrasas are also part of that system [madaris bhi us nizam main hein]. They feed and house many poor children and provide them with training for later employment. For example: here at Nadwa.

Nadwa's materials and statements by its leadership contain no mention of its role in such 'welfare' for the poor. Indeed, the pride that Nadwa students have in the Islamic scholarship at their institution suggests that to characterize this instruction as charity would be disingenuous. Yet, while this view of madrasas as part of the welfare safety net for poor Muslims was not an oft-discussed theme, it did come up occasionally. Jamal, ${ }^{7}$ a senior Nadwa student told me, mixing English with Urdu:

Even though students expect more from Nadwa-better English and whatnot...what [Nadwa] is doing is really good. At least Nadwa is providing education free to students! So many students are poor-so poor that I buy them breakfast if they've run out of money. These students would just go to some crappy government school -or not go to school at all. ${ }^{8}$

Although religious education was explicitly recognized as Nadwa's mission, it played a role in providing free basic education of an acceptable quality. This view remained at the forefront of both students' and administrators' views. As many of my contacts at Nadwa saw it, the Indian public (and madrasa students themselves) may criticize madrasa education for its failings, but it still often remained seen as better than comparable local government schools. 
12 Even as they complained about them, students understood why certain aspects of Nadwa education were low-quality, such as the English instruction, or why there was a lack of topics such as accounting and management that students might even find helpful in their work as leaders of mosque organizations or madrasas. Nadwa had trouble recruiting or maintaining high-quality instructors with credentials for such positions, since other institutions could pay better salaries. Business education and English-language were simply in very high demand in Lucknow. Nadwa administration had chosen to spend its resources elsewhere given that many madrasa students could take such courses offcampus at reasonable rates, and many students affordably did so. The curriculum generally devoted one class out of seven to non-religious subjects. For example, a thirdyear student's schedule included these seven classes on typical day: Qur'an, hadith, Islamic jurisprudence (figh), principles of jurisprudence, advanced juridical commentaries, Arabic literature, philosophy, and English and/or General Education (for a full description of the Nadwa curriculum, see Sikand 2005).

13 As a parallel system to government schools, Nadwa and other madrasas operate on private religious alms-donations-not costing Indian taxpayers a rupee-in order to extend basic literacy, and advanced literary and humanities education to upwardly mobile Muslims. Lucknow Muslims of means give religious charity regularly, as almsgiving in Islam is not merely an act of goodwill but is also an annual obligation revealed in scriptures; for Sunnis, the rate is $2.5 \%$ of assets and for Shi'a it is $20 \%$ of profits. Through ethnographic observation and interviews in the Aminabad bazaar of Lucknow, I gained a broadly comprehensive picture of almsgiving in the city.. A majority of Lucknow Muslims who give Islamic charity do so primarily to madrasas, more than to other Muslim organizations, once they have fulfilled obligations to needy relatives and neighbours. Madrasas such as Nadwa receive the majority of their income through these channels, fundraising locally and in major cities in India (see Taylor 2015; Jeffery et al. 2007).

14 The administration reported to me that $60 \%$ of students receive scholarships in the form of fee waivers and stipends, due largely to the institution's charitably fundraised income. Education at Nadwa is free for all students, rich or poor, as the school charges no tuition fees. The only fees are an application fee and fees for room and board. Over half of the students in a small sample to whom I gave the questionnaire were receiving a complete scholarship (wazifah) from Nadwa (16 of 25; 64\%), and this percentage in the questionnaire's stratified sample is comparable to that reported for the overall student body (60\%). The scholarship included room and board (costing 730 rupees per month, $\$ 13)$, sets of clothes tailored on-campus, and a small 100 rupee stipend for 'pocket change' (jebi kharch). Two other students (8\%) were receiving half-scholarships of 350 rupees discount off the total. Scholarships were distributed on the basis of family need, which was determined through an evaluation visit by a Nadwa representative to the student's home.

Zahir was a 26-year old $3^{\text {rd }}$ year student at Nadwa who came from a small village near the Nepal border and was receiving a full scholarship for his studies. He related his caste as 'vegetable seller' (sabzi-farosh) though his parents and uncles were farmers. His father died when he was quite young, and as an orphaned ${ }^{9}$ boy he left his mother and enrolled in a small village madrasa near Gorakhpur and subsequently won admittance into Nadwa. A diminutive young man with an intense gaze, Zahir explained, 'I began madrasa for two reasons. First, I didn't want to have an entirely worldly (dunyavi) education. Second, I had 
no money. They're not supposed to take fees but many government school teachers do.' ${ }^{10}$ His older brother had already been sent to a Hindi-medium school an hour journey from his home, which expended his uncles' funds such that there were none left for Zahir's education. But Zahir refused to join manual labour or farming work, 'Our village had basically no literate people! There was a madrasa operating in the next village over, but ours had no school at all. It's a very backward [pasmandah] place.' Capitalizing on the opportunities for language study at madrasas, he had learned Hindi up through $5^{\text {th }}$ standard and was currently energetically engaged in his Arabic studies at Nadwa. He had won six awards in Nadwa's speech-giving society for spoken Arabic. Throughout, he also studied in Urdu. '[Nadwa] is the best madrasa in India. In others, there is only religious studies [deeni tahlim] but here there is both,' he explained, presumably referring to the English classes and General Education course which covered the basics of the government school curriculum in one class.

Zahir's case is representative of other scholarship students in terms of illustrating educational opportunities afforded many of the Muslim families with sons who attend Nadwa. The language instruction at madrasas, such as basic literacy in Hindi (taught at the primary level in all madrasas) and the additional languages whether Urdu, Arabic (as in Nadwa), or Persian was the most transferable credential for students' entry into the university system. Zahir planned, as did many other Nadwa students, to sit for the government exam that certified madrasa graduates with a 'matric' (matriculation) degree, or $10^{\text {th }}$ standard equivalency.

The results of the stratified sample I took of the student body show the impact of Nadwa's free education upon social mobility for a snapshot of 25 students. Over a third (35\%) of these Nadwa students' parents had no formal schooling. Most of that $35 \%$ had parents who were farmers or manual labourers. Over $50 \%$ of them had parents with an education of $12^{\text {th }}$ standard or less. These students were the first in their family to receive an education above Post-Matric ( $12^{\text {th }}$ standard; i.e. finishing secondary school). Nearly all Nadwa students, despite their often humble origins, would soon be proud holders of a BA or MA degrees, obtained through simply sitting for equivalency credentialing exams once they finished Nadwa's 'alim (BA) or faziliat (MA) courses.

North Indians, particularly those from lower classes and castes, embrace education as a means to social mobility and even fetishize schooling for its cultural capital and apparent role in 'development' (Jeffrey et al. 2008). The Constitution of India guarantees education as a right free of cost for all children provided-at a minimum-by the government. Unfortunately, the continuing educational value of madrasas is very much a result of the massive failure of the Indian government to provide basic education. As Corbridge et al. (2013: 53) wrote, 'The Indian state's failure to satisfy this Directive [of the Constitutional right to education] is perhaps the most damning of its failures in the post-Independence period' of all the state's efforts at development for the nation.

The demand for education in India has simply been too vast to be met by government and private institutions. '[Indian] madrasas exist in a larger ecology of educational provision in which education over all, and particularly rural education, has been sadly deficient' (Metcalf 2007: L1514). Over 30 million children are out of school nationwide, the highest absolute number of any country in the world, and Muslims make up a proportionally lower amount of graduates-comprising $11 \%$ of the population over 20 but only $6 \%$ of higher education graduates (Riaz 2008: 164-66). Moreover, the liberalization of the Indian economy in the late 1990s strongly impacted education, as the government granted 
massive numbers of certifications to private schools and universities that now make up the majority of educational institutions in cities and towns, even as government spending dropped (Gupta 2011: 29-31). This shift is part of a larger trend, as India's government increasingly defers responsibility for welfare services from public to private domains (Dreze \& Sen 1995; Harriss-White 2003: 41-44). However, despite the gains that private educational entrepreneurs have made in opening new private schools, their profit-driven motive and fee-based structure essentially shut out lower-income students from such opportunities (Jeffery et al. 2005). High-quality private schools were also rare in Muslim areas of Lucknow (cf. Metcalf 2007: L1514), and the ones that I visited were of very low quality and I heard numerous stories of corruption.

\section{Employment prospects}

A majority of graduates aspired to religious occupations. Jamal, whose grandfather, uncles, and some cousins were Nadwa graduates, related to me his experience:

Government schools here are crap. You learn virtually nothing there. My uncle teaches at one. His students won't get a job as anything but a rickshaw driver.

Madrasa graduates, though, they can make a minimum of at least 10,000 rupees a month for teaching 'tuitions' [lessons in Urdu, Arabic, or Qur'an]. You'll get at least 1,000 per family. Maulanas will tell you they only make 300 rupees per family to be modest, but that's not really true-most pay more and everyone knows it.

'Alims [madrasa graduates, pl. 'ulama] can always get jobs. There are new mosques being built all the time. Look around Lucknow and you can see them. The prior 'alim is often moving out as the imam of the mosque to other things-to go get a BA, to teach in a new Islamic school, or teach in a madrasa-so there's jobs. ${ }^{11}$

Being the imam of a mosque certainly did not pay well, being based largely on donations from the community board of the mosque and collections at Friday congregational prayers when a box or bag was passed around the rows of worshipers. Nevertheless, it was seen as a very stable job with a regular-if fluctuating-income. As I had observed myself, in addition to hearing from Jamal and all other interviewees, many imams supplemented their mosque-income with private tuitions for wealthy Muslim families who wanted their children to learn the Qur'an and Urdu script at home, even as they attended private English-medium schools during the day. Religious occupations, as Jamal related, were constantly opening up especially in urban areas. Another interviewee, Ehsan, confirmed this view of his class fellows:

People from Bihar [from humble backgrounds], they study here only to get earnings [afterward]! They are so brilliant. They work so hard...They don't have much money, not even enough for continuing studies. That's why they came to the madrasa in the first place, because everything was paid for. Even if they don't do well in their studies, they at least will receive a job at a mosque. ${ }^{12}$

In the view of these students, and their families that supported their entry into the madrasa, Nadwa graduates were essentially guaranteed employment of some sort-which was not a sure thing in the economy at large, as urban unemployment hovered around 29\% in UP (NSS 2013: 277). Students who worked particularly hard could rise to teach in prestigious madrasas like Nadwa, or even pursue further Islamic education abroad in Egypt or Saudi Arabia, while even the most mediocre student believed they would have little trouble securing work at one of the numerous mosques in big cities such as Lucknow. 
21 madrasa graduate would likely obtain with those of graduates of government schools who remained barely literate. Unlike thousands of other secondary school graduates that pursued low-skilled work in north India's supply-heavy labour market, madrasa graduates could claim a specialized niche. Even though in Lucknow elite madrasa students such as Nadwa graduates were in the most demand, occupational opportunities in the religious sector in India overall do seem to be growing nearly as quickly as the pool of madrasa graduates, even as the Indian economy modernizes and globalizes. A discourse analysis of education narratives in a western region of UP uncovered steady, if low, ${ }^{13}$ levels of popularity for religious occupations for youth educated in madrasas. 'Interviews suggest that this form of work is becoming more popular' (Jeffrey et al. 2004: 93). more 'modern' than the village-based occupations, as the growth of mosques in recent decades has created a remarkable rise in urban-based opportunities for youth whose primary goal is to migrate from home districts. This view was common even among students, such as Zahir above, who had obtained non-madrasa credentials already but nevertheless aimed to teach in a madrasa himself, albeit preferring to start his own. Research by Jeffrey et al. (2004: 974) uncovered similar sentiments among Muslim youth in Bijnor, many of whom 'saw nothing shameful about having collected mainstream qualifications and wanting to do religious work.' Unlike agriculture, daily wage labour and other manual work, religious occupations were viewed as respectable jobs that evidenced an individual's social standing as an educated person and their capacity for academic learning, even if they had only attended a madrasa (Jeffrey et al. 2004: 974).

While at a minimum all students knew they could avoid manual labour and join the educated classes as the prayer leader in a mosque or teacher at a madrasa, they often hoped they could become university-educated professionals. As one student put it, 'Every Nadwa graduate who really works hard, at a minimum, can get a job as a translator,' referring to the vibrant printing enterprises that distributed books in English, Hindi, Urdu, Arabic, and Persian. Muslims I spoke with outside of Nadwa had similar views, sharing stories of Nadwa graduates who worked in Lucknow's travel agencies, universities, for newspapers, and even as accountants in construction companies.

Nadwa is distinct among India's madrasas for its long tradition of Arabic instruction, which opens up further opportunities for Indian students (Hartung 2006). Nadwa's founders designed the institution explicitly with an eye towards Arabia, claiming to even have improved upon the outdated management and instruction in Egypt and Saudi. When a young Moroccan student named al-Hilali arrived at al-Azhar to study in 1917, his Egyptian mentor 'described the education [in India] as being much more organized and therefore effective' and counselled him to travel onward to Lucknow. He studied at Nadwa, then later taught there as the Arabic instructor (Hartung 2006: 138).

Today, as well, this high-quality Arabic instruction at Nadwa makes graduates particularly competitive in India's religious economy. In mosques across India, it is common practice during Friday prayers for the prayer leader (imam) to give a sermon in Arabic, if possible. Nadwa graduates in particular, however, were distinguished by their intensive study of Arabic. Their lessons included classical Qur'anic Arabic, but also required them to become familiar with a variety of dialectical variations: non-Islamic

South Asia Multidisciplinary Academic Journal, 11 | 2015 
Arabic poetry, conversational Arabic, formalized Arabic of the news media, and the genre conventions of Arabic sermons. Many Nadwi instructors themselves have lived or travelled in Arab nations. The classroom curriculum was supported by numerous clubs that fostered an environment for Arabic proficiency. A speech club (an-nadi al-'arabi) held weekly events for students to give Arabic sermons. Students ran Arabic conversation and study groups daily in the mosque. A student-run journal printed articles in Arabic by students. In the dorms and administrative buildings, Arabic newspapers, magazines, and journals were lying around for consumption; at least one I saw is printed at Nadwa and circulated among its donors and supporters (Arab and expatriate Indian alike) in Arab nations. Most Nadwa students in interviews, in response to my standard question about how their home community perceived them and their Nadwa studies, cited knowledge of Arabic as a key achievement. One said:

People respect me more when I go home now. I give sermons on Fridays. There have been imams in my village for years, but they don't give Arabic sermons! I am the youngest 'alim of all of them, and I am the one that leads tarawi [long Qur'anic readings] and sermons. I give these sermons without preparations! They were so impressed. They'll say, 'Look! This boy grew up in this very village and is now giving speeches in Arabic!'

A high-quality madrasa education provides alternative tracks to employment outside of one's home region, even abroad in the Middle East, due to the relative demand for a small number of Arabic speakers. ${ }^{14}$ In this regard, Nadwa provided a form of education only available within religious schooling. The appeal of Arabic-language and Islamic instruction has a pull on Muslim students and their families from all strata of society who would not otherwise have access to such chances for travel and rarefied learning. As such, many upper-class students gain skills in Nadwa not available at government or private schools, and it would be a mistake to consider madrasa schooling as a tool of social mobility only for the underprivileged.

Students who graduated from Nadwa with particular skill in Arabic could make even further use of Nadwa's contacts, especially for international fundraising. Two preachers that I knew in Lucknow who had graduated from Nadwa both showed me their fundraising materials printed in India for use when they travelled to Saudi Arabia. The glossy pages between clear plastic covers and a spiral binding contained colour photographs of 'modern' madrasas for which these two graduates fundraised. One had already begun construction on an educational campus that would contain separate Islamic schools for girls and for boys that taught the government curriculum as well as Islamic sciences from primary school through college, with additional plans for a health clinic and dispensary.

Nadwa has long been known as north India's institution most closely linked with Islamic scholarly circles in the Arab Middle East (Hartung 2006; Zaman 2002). Dr Khalid Bin Ali alGhamidi, one of the men known as Imam-e-Ka'ba (leader of the Ka'ba) who lead prayers at Mecca's most sacred mosque, paid a visit by invitation to Nadwa during my research in May 2012. Students overheard him discussing a prior visit to the madrasa campus when he had asked why the mosque was so hot, then proceeded to donate sufficient funds to line the walls and ceiling with air conditioners (within each archway in Figure 1). Visitors from Mecca had great respect for Nadwa and often made financial contributions to the school, in cash, during their visits, other senior students confided. While the donations were not large enough to constitute a significant portion of the budget, they did enable Nadwa to make certain improvements. 
FIGURE 1

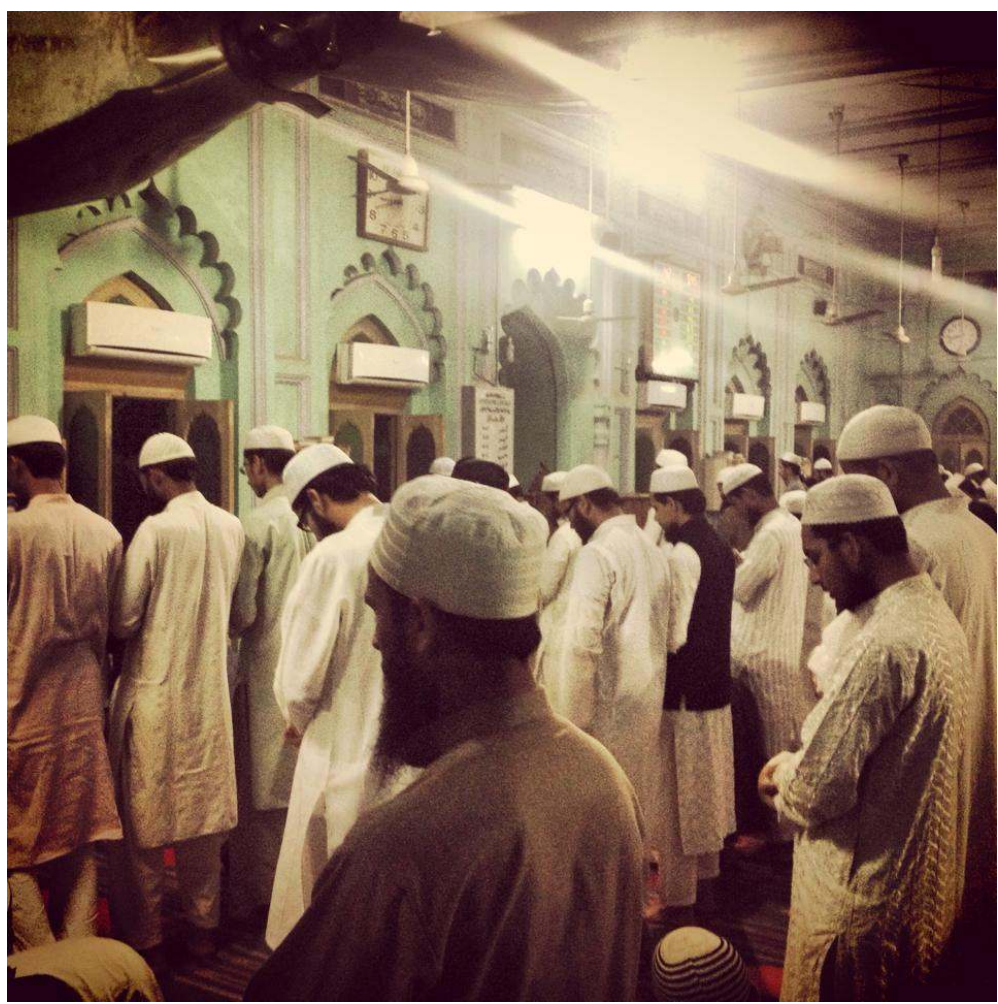

INTERIOR OF NADWA MOSQUE DURING NIgHT PRAYERS

CREDIT: NIHAL AHMED KHAN

Such international ties were also sources of hope for enterprising students. Omar was one of the tallest madrasa students at Nadwa, although still bone-thin, and he stuck out in the crowd outside the mosque when I approached him and asked for an interview. He was a business student who received a Bachelor of Commerce at Lucknow University before enrolling in Nadwa, and his pedigree evidenced itself in the way he spoke and envisioned his future, but his ultimate goal was firm:

I want to work in service to Islam [khidmat-i $\operatorname{din}]$...and open a 'high-tech' madrasa. Universities are so beautiful, with the best tiles and buildings, and we should have more madrasas like that, because this is where the Holy Qur'an is taught!...

I'll make a 'proforma' [business plan] which I can give to wealthy people. I'll contact partners in other cities like Mumbai and in the Emirates online to get their support. Mostly the rich madrasa donors are there, each one with eighty lakh rupees $[\$ 14,800]$ to give! There are enough alms-givers for sure. But everyone wants to see the results [natijeh]! We will have to show results. ${ }^{15}$

Omar was correct in thinking that wealthy Muslim donors in large cities and abroad responded to colourfully illustrated business plans and evidence-based annual reports with 'results' (natijeh). He planned to print his business plan and reports in English and Arabic that he would write himself and get checked by senior Nadwa graduates he knew.

Arabic language skills led many other such students to fundraise beyond India, once they graduated from Nadwa, utilizing a linguistic talent and cultural capital not obtainable in universities. I personally met two madrasa graduates in Lucknow who had recently begun residential madrasas, and fundraised about $\$ 10,000$ apiece from urban donors with glossy colour reports in Urdu, English, and Arabic. While Indian 'ulama rarely have the upfront 
resources required to travel themselves to the Middle East in order to fundraise for small madrasas, the Arabic reports are for Muslims visiting from the Emirates or Saudi Arabia who occasionally tour Indian madrasas, curious about these institutions of higher learning whose fame they have read about in their home countries and sympathetic for the (comparatively) poor conditions for Indian students studying there. For example, instructional texts on hadith that were penned by Nadwa's most famous director, Maulana Sayyid Abu'l Hasan 'Ali Nadwi (d. 1999) are still taught in Saudi Arabian seminaries and recognized as classics in the genre of hadith studies (Zaman 2002: 162).

\section{Social mobility}

Across all interviews I performed, students responded that they saw a difference in how their families and home communities perceived them once they began their studies at Nadwa, illustrating the potential cultural capital acquisition and social mobility resulting from full-time madrasa study. Completing even a year of studies in Nadwa invariably increased students' perceptions of their own status in their communities and the world at large. This perception of increased status was true even for higher status students (i.e. students with relatives or peers of high socioeconomic positions in society, those who also had completed non-madrasa schooling, and higher caste students) but the status gains from a Nadwa education were much more salient for students from humbler backgrounds.

31 One sunny day, I met a senior student, Wahid, for tea. Other students rudely pushed ahead of us in line as we reached for teacups, eliciting glares, then a sigh, from Wahid. He confided in me once we sat down, 'Students from rural [dehati] and poor [gharib] backgrounds are taking over Nadwa. It's not as fine [sharif] a madrasa as it used to be.' ${ }^{16}$ Putting aside Wahid's haughty air, his remark reflected an actual demographic shift occurring in the Nadwa student body. Nadwa faculty and students alike told me that in recent decades Indians from lower societal strata were entering the madrasa in greater numbers. Nadwa over the years has also allowed its numbers to swell (as has Deoband) from 600 students in the 1980s to over 3,000 students today. The absolute number (and proportion) of lower-strata students has increased. ${ }^{17}$ One senior instructor with whom I spoke emphasized that, 'When Nadwa began there were mostly wealthy people's children attending....Now, it has become more public [awāmi].'

Other interviews, however, indicated a caste dimension to this demographic shift. Muslims in Lucknow often mention how Islam lays a strong emphasis on equality /across racial and ethnic boundaries, and many educated Muslims would claim to me, 'caste does not exist among Muslims.' As my fieldwork progressed, however, I observed occasions in which Muslims attended to boundaries of caste-like communities, most overtly of course in marriage arrangements (cf. Basant \& Shariff 2009: 4-5). A few interviews with Nadwa students confirmed that madrasas were, nonetheless, one institution which transcended caste boundaries. Answering my interview question regarding an increase in perceived social status ('izzat, ehtarām) upon returning to his home village, Ehsan said, 'Yes, I did [notice increased status] because everyone sees Nadwa as a good opportunity to become a defender of Islam. Now anyone can study in Nadwa-it's very democratic [jomhürī].' community, who is studying on full scholarship at Nadwa, and his hometown of Mewat is 
highly segregated into Hindu and Muslim groups, following riots during his grandparents' time. The Meo community there has been designated part of the 'Other Backward Classes' (OBC) and thus eligible for reservations. I asked him my standard interview question of what changes he perceived in how his hometown received him after his Nadwa studies began, and his face broke into a wide smile:

First my older brother, and now me, have studied at Nadwa...There were no other madrasa-educated people ['alim] in the whole village! ${ }^{18}$

I asked him if he had ever led prayer in the masjid at home, where Muslims of various caste backgrounds attend.

I didn't used to, but I have begun to do it. The imam asked me to. He also asked me to give the [Friday] sermons! The first time [he asked], I hesitated. I felt weird. But [that imam] respects me in his heart. He said, 'Give the sermon and lead prayer as long as you are here. People will be pleased to be able to pray behind an 'alim.

He now leads prayer in the masjid every time he returns home on break. The imam there was not madrasa-educated but rather has merely memorized the Qur'an. Custom in north India dictates that the man who has studied (and memorized) the most Qur'anic verses or has the greatest degree of Islamic learning, is often designated as the leader during prayer times regardless of who is the sitting preacher of the mosque. Unlike caste status or other ascribed status, scriptural learning is acquired by an individual, and thus madrasa studies are consistent with the modern ethos of individual advancement through personal endeavour. As Asif's story illustrated, in Muslim communities such as Mewat that increasingly prize scriptural learning, lower-caste Muslims have a chance at societal mobility through the respectable pursuit of madrasa knowledge. Those who pursue studies as an 'alim are encountering opportunities that surprise even themselves.

Farooq, another student from a low caste background (he refused to answer which caste) spoke openly about Nadwa's environment of freedom and equality among castes and across other social divisions. When I asked if he perceived an increase in his relatives' pride and esteem of him, he replied:

So much so [bahut essa hai]! I've seen it. Actually, whoever's child is a memorizer of the Qur'an [hăfiz] or-even better-studies in a madrasa, they get respect everywhere they go, especially for the sake of [the student's] parents who get so much respect from others, 'His son is the one studying in that madrasa, getting the religion [dìn], gaining knowledge ['ilm]. Everyone basically wants their children to become an 'alim!

When I came to Nadwa-in particular-I saw that Nadwi graduates are people who can stand on any stage [and give speeches] in front of anybody, and in any language. I've seen many Nadwis speak and work throughout society and they gain people's approval.

Nadwa's aim is to keep Muslims united-unity [itehād] is the goal. There's no ideological disagreement [iktalāf] here. Just as there is complete equality in Islam, I see that equality here, too. All sects [masālak] are [represented] here. All types of people. It's that sort of unity. ${ }^{19}$

As Farooq's explanations illustrate, some degree of Islamic learning is of value in rural Muslim families of his hometown, even the sort of learning children obtain in memorizing the Qur'an in local religious schools. Nevertheless, he also emphasized that Nadwa (unlike some smaller or less famous madrasas) is viewed as an institution with sufficiently high-quality instruction that individual students' efforts are rewarded with broad-based recognition in their communities. The mission of Nadwa to serve as a centre of all-India Muslim leadership, moreover, keeps a certain focus on scriptural knowledge for all Indian Muslims, explicitly side-lining caste or sectarian orientation. ${ }^{20}$ It is this 
'unity' that Farooq and other classmates I spoke to appreciate and benefit from, when they perceive that their academic achievements go unhindered by prejudices they felt in other contexts.

Madrasas in contemporary India, not only Nadwa, can constitute a key forum for reworking social statuses and de-linking them from customary caste hierarchies, as Arshad Alam has demonstrated in his study of caste groups and the politics of madrasa leadership. 'The importance of upward mobility is most radically felt in the symbolic domain,' he wrote. 'A young boy belonging to one of the many low castes and a firstgeneration learner...leading the Islamic prayer disrupts many social solidarities of the old order...most importantly, caste' (Alam 2011:204-05). As the opportunity to study in madrasas reaches more students in remote villages, and even local madrasas offer a route to the elite, nationally renowned madrasas with which they are affiliated, they also become sites of 'low-caste Muslims' aspirations to find a place within the textual tradition of Islam' (Alam 2011: 202).

Yet caste is by no means disappearing as a relevant cultural mark of distinction in India. While the decline of the hierarchical system founded on pollution and purity is well underway, castes are increasingly seen as more 'horizontal' arrangements in society. Caste groups retain a sense of identity and solidarity through continuing mutual support and inter-marriage, even in cities. Status gains by lower castes have not made caste irrelevant, it has merely become less of a basis for discrimination (Corbridge et al. 2013).

Another reason for the continuing, if not increasing, utilization of madrasa education by Muslims in India is the status attributed to the elite madrasas of India and their graduates, particularly Deoband and Nadwa but also the Dar al-'Ulūm in Saharanpur and others. Alam (2011) provides an in-depth examination of the reproduction of cultural capital (Bourdieu 1977) in madrasa education, usefully delineating 'social fields' in which such cultural capital is most salient. As one explicit marker of the salience of such societal status, madrasa graduates continue to affix 'Qasmi' (signifying a Deoband pedigree) or 'Nadwi' after or in place of their last names, a practice that I observed even among those graduates who joined businesses or took university positions in Lucknow where presumably their madrasa credentials were not professionally relevant. This theme is also illustrated in many of the interviews I carried out with students, even with those who came from middle-class, land-owning, or otherwise already high-status family backgrounds.

\section{Conclusion}

This article illustrates how Muslim students view madrasa studies as one credential among many that are available in modern India. They take for granted that the contemporary Lucknow economy is comprised of highly differentiated divisions of labour, including growing jobs in religious occupations. They explicitly reject the (widespread) myopic public perception that becoming a doctor or engineer is the best path to employment in India's diverse labour market. This religious credential is often sufficient for achieving students' goals in the modern economy, in the world beyond their village and beyond the calm of madrasa walls: it brings cultural capital among urban educated Muslims which they lacked previously, social status in their home villages, escape from the remnants of caste prejudice, a back-door into university education via government credentialing exams, and Islamic learning and Arabic skills that open the 
doors to geographical mobility to other regions and, indeed, other countries. While students are certainly aware of and accept the criticisms of madrasa education, they also believe government education to be a less effective alternative. On the other hand, feebased English-medium education such as in convent schools remains out of the reach of many. Madrasa education was thus much more than merely a means of preserving cultural identity as a religious minority. For Muslims seeking upward mobility, it was perceived as having real economic utility in imparting some degree of white-collar career skills and stable employment-at little or no cost to students' families.

At other times, however, this religious credential was insufficient for their goals and students explicitly criticized madrasa education for many of the same reasons as policymakers or others who seek to reform it. Nearly all students lamented the low quality of English instruction at Nadwa. Many sought additional MA, MBA, and PhD degrees from universities, even concurrent with their madrasa studies although this went against Nadwa's policies. Other students declared that their prior education in rural schools did not prepare them, and Nadwa studies were a critical intermediary step for university, which also brings BA-equivalency upon completion, and told me in detail of their plans to gain acceptance to the Lucknow University that was tantalizingly adjacent to the grounds of Nadwa.

Yet taken as a whole, these data on Nadwa emphasize its place within the economy of Lucknow's religious sphere that links it to wealthy Muslim donors in India and abroad to foster channels of upward social mobility. As such, these data represent Nadwa not only in the typically understood role of madrasas in reproducing Islamic knowledge, but also represent the larger relationships of exchange in which madrasas are embedded and which they co-create. The transnational dimension of this social mobility is a critical but as-yet understudied theme. A more specific focus on international ties of Nadwa graduates was outside the scope of this research; such a comprehensive study of employment and fundraising opportunities abroad awaits its author. At a time when madrasas are so widely debated in Indian media and public discourse, however, the students' views on the religious labour market of Lucknow presented here do capture a less studied aspect of socioeconomic development in north India, showing madrasas such as Nadwa within a flow of alms, wealth, and job opportunities that lower-class Muslims of Lucknow perceive as having a substantial impact. Such a rationalization of religion has not necessarily led to the withering away of religion from the public sphere, as Max Weber (1978) proposed (cf. Casanova 1994; Eickelman \& Anderson 1999; Zaman 2002), but rather to an advanced division of labour between mutually interdependent sectors and sub-economies-including clerical occupations and religious education.

\section{BIBLIOGRAPHY}

Alam, Arshad (2011) Inside a Madrasa: Knowledge, Power and Islamic Identity in India. Delhi: Taylor \& Francis. 
Ali, Syed (2002) 'Collective and Elective Ethnicity: Caste among Urban Muslims in India', Sociological Forum, 17, pp. 593-620.

Bano, Masooda (2014) 'Madrasa Reforms and Islamic Modernism in Bangladesh', Modern Asian Studies, 48(4), pp. 911-39.

Basit, Abdul (2012) The Global Muslim Community at a Crossroads: Understanding Religious Beliefs, Practices, and Infighting to End the Conflict, Santa Barbara: Praeger.

Casanova, Jose (1994) Public Religions in the Modern World, Chicago: University of Chicago Press.

Corbridge, Stuart; Harriss, John; Jeffrey, Craig (2013) India Today: Economy, Politics and Society, Cambridge UK: Polity Press.

Dreze, Jean; Sen, Amartya (1999) India: Economic Development and Social Opportunity. Oxford: Oxford University Press.

Eickelman, Dale. F.; Anderson, Jon W. (1999) New Media in the Muslim World: The Emerging Public Sphere, Bloomington: Indiana University Press.

Gupta, Akhil (2012) Red Tape: Bureaucracy, Structural Violence, and Poverty in India, Durham, N.C.: Duke University Press.

Gupta, Nandini (2012) Reading with Allah: Madrasas in West Bengal, New York: Routledge.

Harriss-White, Barbara (2003) India Working: Essays on Society and Economy, Cambridge: Cambridge University Press.

Hartung, Jean-Peter (2006a) 'The Nadwat al-'ulamâ': Chief Patron of Madrasa Education in India and a Turntable to the Arab World', in Helmut Reifeld \& J.-P. Hartung (eds.), Islamic Education, Diversity and National Identity : Dīnì Madāris in India Post 9/11, New Delhi: Sage Publications, pp. 13557.

Hartung, Jean-Peter (2006b) 'Towards a Reform of the Indian Madrasa? An Introduction', in J.-P. Hartung \& Helmut Reifeld (eds.), Islamic Education, Diversity and National Identity: Dini Madaris in India Post 9/11, Delhi: Sage Publications, pp. 11-38.

Hefner, Robert W.; Zaman, Muhammad Qasim (2007) Schooling Islam: The Culture and Politics of Modern Muslim Education, Princeton (N.J.): Princeton University Press.

Ingram, Brannon D. (2014) 'The Portable Madrasa: Print, publics, and the authority of the Deobandi 'ulama', Modern Asian Studies, 48(4), pp. 845-71.

Jamous, Raymond (2003) Kinship and Ritual among the Meo of Northern India, Delhi: Oxford University Press.

Jeffrey, Craig; Jeffery, Patricia; Jeffery, Roger (2004) “A Useless Thing!' or 'Nectar of the Gods?' The Cultural Production of Education and Young Men's Struggles for Respect in Liberalizing North India', Annals of the Association of American Geographers, 94(4), pp. 961-81.

Jeffery, Roger; Jeffery, Patricia; Jeffrey, Craig (2005) 'Social Inequalities and the Privatisation of Secondary Schooling in North India', in R. Chopra \& P. Jeffery (eds.), Educational Regimes in Contemporary India: Essays on Education in a Changing Global Context, London: Thousand Oaks, pp. 4161

Jeffrey, Craig; Jeffery, Patricia; Jeffery, Roger (2007) 'Investing in the Future: Education in the Social and Cultural Reproduction of Muslims in UP', in Mushirul Hasan (ed.), Living with Secularism: The Destiny of India's Muslims, New Delhi: Manohar, pp. 63-89. 
Jeffrey, Craig; Jeffery, Patricia; Jeffery, Roger (2008) Degrees Without Freedom? Education, Masculinities, and Unemployment in North India, Palo Alto: Stanford University Press.

Jhingran, Saral (2010) Madrasa Education in Modern India: A Study, New Delhi: Manohar.

Jones, Justin (2011) Shi'a Islam in Colonial India: Religion, Community and Sectarianism, Cambridge: Cambridge University Press.

Metcalf, Barbara Daly (1982) Islamic Revival in British India: Deoband, 1860-1900, Oxford: Oxford University Press.

Metcalf, Barbara Daly (1984) Moral Conduct and Authority: The Place of Adab in South Asian Islam, Berkeley: University of California Press.

Metcalf, Barbara Daly (2004) Islamic Contestations: Essays on Muslims in India and Pakistan, Oxford: Oxford University Press.

Metcalf, Barbara Daly (2007) 'Madrasas and Minorities in Secular India', in R. W. Hefner \& M. Q. Zaman (eds.), Schooling Islam: The Culture and Politics of Modern Muslim Education, Princeton: Princeton University Press, pp. 87-106.

Osella, Filippo; Osella, Caroline (2008) 'Islamic reformism in South Asia', Modern Asian Studies, 42 (2-3), pp. 247-57.

Riaz, Ali (2008) Faithful Education: Madrassahs in South Asia,New Brunswick (NJ): Rutgers University Press.

Robinson, Francis (1993) 'Technology and Religious Change : Islam and the Impact of Print', Modern Asian Studies, 27(1), pp. 229-51.

Robinson, Francis (2001) The Ulama of Farangi Mahall and Islamic Culture in South Asia, New Delhi: Permanent Black.

Robinson, Francis (2008) 'Islamic Reform and Modernities in South Asia', Modern Asian Studies, 42 (2-3), pp. 259-81.

Rudolph, Lloyd L.; Rudolph, Susanne Hoeber (1967) The Modernity of Tradition: Political Development in India, Chicago: University of Chicago Press.

Sachar, Rajinder (2006) A Report on the Muslim Community of India: High Level Committee Report on Social, Economic, and Educational Status of the Muslim Community of India, Government of India, Delhi: Government of India.

Sikand, Yoginder (2005) Bastions of the Believers: Madrasas and Islamic Education in India, Mumbai: Penguin Press.

Sikand, Yoginder (2006) 'The Indian Madaris and the Agenda of Reform', in J.-P. Hartung \& Helmut Reifeld (eds.), Islamic Education, Diversity and National Identity: Dini Madaris in India Post 9/11, Delhi: Sage Publications, pp. 269-84.

Taylor, Christopher B. (2015) Islamic Charity in India: Ethical Entrepreneurism and the Ritual, Revival, and Reform of Zakat among a Muslim Minority, PhD Dissertation, Boston University.

Weber, Max (1978) Economy and Society: An Outline of Interpretive Sociology, Berkeley: University of California Press.

Winkelmann, Mareike Jule (2005) From Behind the Curtain: A Study of Girls' Madrasa in India, Amsterdam: Amsterdam University Press.

Zaman, Muhammad Qasim (1999) 'Religious education and the rhetoric of reform: The Madrasa in British India and Pakistan', Comparative Studies in Society and History, 41(2), pp. 294-323. 
Zaman, Muhammad Qasim (2002) The Ulama in Contemporary Islam: Custodians of Change, Princeton: Princeton University Press.

\section{NOTES}

1. To name a few by way of example, the national government welfare schemes targeted at madrasas include the Sarva Shiksha Abhiyan (SSA) and the Area Intensive and Madrasa Modernization Programme, as well as more recent 2014 additions: Scheme for Providing Quality Education in Madarsas (SPQEM), the Infrastructure Development in Minority Institutions (IDMI), and the Maulana Azad Talim-e-Balighan (education for adults) scheme. Many state-level schemes also exist.

2. See for example, Mohammad Wajihuddin. 2011. 'The Price of Moderation,' Times of India, July 31, 2011. http://timesofindia.indiatimes.com/city/mumbai/The-price-of-moderation/ articleshow/9427018.cms

3. All quotations from interviews in this article are translated by the author from the Urdu, unless noted as spoken in English.

4. Page numbers prefaced with an 'L' in citations refer to e-book Locations in the Kindle e-book edition.

5. Madrasa attendance rates are significantly higher in north India than in other regions. The Sachar Committee reported as follows: East 3.5\%, South 1.5\%, West 3.5\%, and all-India $4 \%$.

6. While official figures were not available, the caste breakdown for the institution as a whole was estimated at less than one-third students from 'backward' $(\mathrm{OBC})$ or dalit groups, through conversations with the administrative officials and senior instructors.

7. All names of interviewees are pseudonyms. This dialogue was taken from a translated interview transcript audio recorded during fieldwork. All other quotes in this article are also from interview transcripts, unless otherwise indicated, recorded via digital audio or handwritten fieldnotes. All quotes are in Urdu, unless otherwise noted, and were translated into English by the author.

8. Jamal, interview by author, Lucknow, 4 April 2013. Jamal was in his final year of the 'alim (BAequivalency) course at Nadwa, from an upper-class family with many members educated at Nadwa and abroad (including himself), and from a caste in general category.

9. Children without a father are often known as 'orphan' (yatim) in north India, even if their mother is still alive because she is assumed not to have earning power.

10. Zahir, interview by author, Lucknow, 28 June 2013.

11. Jamal, Interview by author, Lucknow, 4 April 2013.

12. Ehsan, interview by author, Lucknow, 3 July 2013. Ehsan's family was upper-class, living in Saudi Arabia for his childhood where his father was a manager for an American corporation, and from a caste in general category (Beg/Moghul).

13. In western UP, the vast majority of respondents engaged in agricultural, artisan, or wage labour. Equal numbers of respondents entered 'business' and 'religious' (mosque and madrasa) employment (Jeffrey et al. 2004: 973-74).

14. The international ties and mobility were not an explicit part of my research questionnaires; however, see Hartung (2006) on the primacy of Nadwa's ties with the Arab region.

15. Omar, interview by author, Lucknow, 23 June 2013. Omar was from a family in which advanced university degrees were common (his father was an engineer and mother held an MA in Islamic Studies), and was of Siddiqi/Sayyid caste.

16. Wahid, informal conversational interview, Lucknow, 6 June 2013. I did not interview Wahid about his socioeconomic or caste background, but he is from a family with elder members educated at Nadwa in prior decades. 
17. This trend is not documented in any official data, as Nadwa administration does not keep records on the caste background of students.

18. Asif, interview by author, Lucknow, 29 June 2013. Asif's father was an uneducated laborer.

19. Farooq, interview by author, Lucknow, 27 June 2013. Farooq was in his first year at Nadwa, was from a family of farmers, and refused to answer the caste background question (the interview carefully addressed sensitivity to discussing caste among Muslims and encouraged respondents to do so if they chose).

20. Of course, Farooq is speaking of various Sunni sects; Shi'a were originally included by Nadwa's founders as part of their revivalist movement, but due to an early conflict, Shi'a were subsequently excluded (Jones 2011: 56 ).

\section{ABSTRACTS}

Lucknow is world-famous for Islamic learning. The city produced the 'ulama of Firangi Mahal, the Sunni seminary of Nadwat al-'Ulama, and the revival and consolidation of a distinctly Indian Shi'ism. In contemporary India, however, critics lament madrasa education's obscurantism, decrying its declining 'usefulness' in the 21st century. Yet a view of madrasas as merely cloistered spaces, impervious to traffic with contemporary life, is misleading. As clamour over 'Muslim backwardness' has become more shrill in recent years, Nadwa madrasa has claimed a role as a provider of welfare in Lucknow. This paper presents the religious sphere in Lucknow, viewed through the case of Nadwa and its students, as a marketplace for jobs in scholarship and ritual leadership as well as a site in the transnational economy of alms. I evaluate its influence in Lucknow's social circles and its ability to maintain prestige (and Saudi funding) amidst 21st century constraints.

INDEX

Keywords: Madrasas, Lucknow, Muslims, development, social mobility, religious charity

\section{AUTHOR}

\section{CHRISTOPHER B. TAYLOR}

Visiting Researcher, Berkley Center for Religion, Peace, and World Affairs, Georgetown University 